\title{
How the Widespread Presence of Historical Private Real Estate Can Contribute to Local Development
}

\author{
Luciano Monti ${ }^{1} \&$ Roberto Cerroni ${ }^{2}$ \\ ${ }^{1}$ Scientific Co-Director of Fondazione Bruno Visentini (Rome-IT), Adjunct Professor of LUISS University (Rome-IT) \\ ${ }^{2}$ Head of Research and Project Office, Fondazione Bruno Visentini (Rome-IT) \\ Correspondence: Luciano Monti, Scientific Co-Director of Fondazione Bruno Visentini (Rome-IT), Adjunct Professor of \\ LUISS University, Rome Italy. E-mail: lmonti@1uiss.it
}

Received: December 12, 2018 Accepted: January 15, 2019 Online Published: February 22, 2019

doi:10.5539/res.v11n1p183 URL: https://doi.org/10.5539/res.v11n1p183

\begin{abstract}
For decades, historical assets have been considered, particularly real estate, as a heritage to be conserved, but limiting the use to museums. The concept of enterprise was considered far removed, if not an indication of the dangerous commodification of the aforementioned assets. On the one hand, the emergence of an ever-increasing demand for cultural services connected to this patrimony, and, on the other hand, the increasing difficulties in finding adequate resources for the conservation of the latter, have pushed a greater number of operators to take into consideration the instrument of cultural industry, the latter whose goal is to secure resources for the maintenance of the artistic historical patrimony by exploiting the potential of the same. Italy is an important test for this challenge, because it can count on an intense pool of historical and artistic heritage, that is unique and unrivalled in the world.

In this paper, therefore, we try to relate the investments necessary for the conservation and enhancement of the Italian private historical real estate assets, with the concentration of the aforementioned in certain realities and with the current local economic development of cultural and creative industries.

The cross analysis shows clearly how the enhancement of private real estate assets is particularly relevant in smaller cities and can represent a stimulus for a specific economic, social and cultural growth model.

However, this opportunity at the local level is unfortunately not always cultivated, therefore, we call for a comprehensive set of structural, long-term interventions in the sector, both at national and supranational level, for not only economic but social revival of private historical heritage.
\end{abstract}

Keywords: cultural heritage, cultural industries, historical artistic real estate, local development

\section{Introduction}

Cultural heritage represents a public good, as it is a natural capital, and the former, like the latter, can be a key factor for economic and social development. Studies on the multiplier effects of culture and cultural attractor theory are widespread. In regard to the former, the measurement of the value of the Baumol \& Bowen multiplier (Baumol \& Bowen, 1996), by Peacock (Peacock, 1966), by Heng et al. (Heng, Choo, \& Ho, 2003), by Kenan Institute Asia (Kenan Institute Asia [KIAsia], 2009) and, recently, the Cultural Heritage Counts for Europe project (Jagodzińska et al., 2015) are two notable contributions. In Italy, studies on the economy of culture (Campa \& Bises, 1982; Causi \& Leon, 1990; Santagata \& Signorello, 2000; Farina, 2003; Santagata, Segre, \& Trimarchi, 2007) on the one hand, focus on the importance of the cultural supply chain within the broader national economic dynamic; on the other hand, there is a desperate need for new directions and perspectives to support cultural policies, conditional on the prevalence of public support.

Despite this, many scholars criticize the use of the multiplier model applied at the local level (Myerscough, 1988; Crompton \& McKay, 1994; Crompton, 2006; McLendon, Klein, Listokin, \& Lahr, 2010). In fact, very often for NUTs greater than 2, the data released by institutional sources for statistical dimensions at NUT 1 level are not clearly disaggregated and, for this reason, it is necessary to collect via field investigations. This method creates problems when comparing studies and very often presents errors and inconsistencies (Reeves, 2002; Everitt, 2009). The quality of the statistical data is therefore extremely important with this method.

In the economy of culture, an increasingly important role is played by cultural enterprise. "Cultural industries" are those industries producing and distributing goods or services that are deemed to be a specific attribute, use or purpose which embodies or conveys cultural expressions, irrespective of the commercial value they may have (European Commission 
[EC], 2010). Companies that often, by size or by organization, have difficulty accessing credit (KEA European Affairs [KEA], 2017).

Sector studies say that the protection and conservation of heritage contributes significantly to the economy of a country ${ }^{1}$ (European Construction Industry Federation [FIEC], 2018; Kancel, Itty, Weill, \& Durieux, 2013; Picard, 2016) and in the United Kingdom other studies have shown that maintenance of historical heritage generates a return on investment of $£ 1.60$ in revenues for ev76ery $£ 1$ invested.

The circumstances that make regeneration and the enhancement of a cultural asset contribute to local development are numerous (McCallum, 2007). These include the fact that the restoration and regeneration of a historic building creates jobs and contributes to the local economy, and unlike other types of buildings, produces an attractive environment for other economic activities, not just those in the tourism sector. The cultural and creative enterprises would be the beneficiaries of this, the first ones set the object of their activity as enjoyment of the historical asset, the latter because they are the source of inspiration for the realization of their products. The study conducted by Bille and Schulze (Bille \& Schulze, 2006) points out the existence of short-term economic impacts associated with the presence on the territory of cultural and creative industries, due to the attractiveness of tourists and residents themselves. In particular, the development of historical buildings contributes to the improvement of the quality of the life of the territory and the sense of belonging. Finally, historic buildings are ideal places for the production of new culture or simply for the carrying out of cultural activities.

Another line of studies (Heilbrun \& Gray, 2004; Titan, Voineagu, \& Todose, 2008), known as "economies of agglomeration", has demonstrated the long-term economic impact of cultural and creative industries, given their ability to create an environment conducive to economic development through the enhancement of human capital, businesses and investments. The concentration of cultural and creative services, in fact, represents an attraction factor for other industries that can use creative capital and services and specialized products of cultural industries.

The cultural sector also produces non-economic impacts that must be taken into account when preparing to outline interventions in favor of this sector. For example, culture has impacts in terms of social cohesion and integration of the most marginal groups (Matarasso, 1997; Council of Europe [CoE], 1998; Bodo \& Bodo, 2008; Vallerand, 2013; European Commission [EC], 2007); in the creation of a new value system (Ingelhart, 2000; Hofstede, 2001); in the formation of new talents and excellence (Throsby, 2001; United Nations General Assembly [UN], 2010); in the development of cultural diversity (United Nations Educational Scientific and Cultural Organization [UNESCO], 2005; Herrera, 2002; Throsby, 2011); but also in the creation of conditions favorable to creativity and innovation (Australian Bureau of Statistics [ABS], 2001; Robinson, 2001; Autor, Levy, \& Murnane, 2003; Cox, 2005; Potts \& Cunningham, 2008; Bakhshi, Mc Vittie, \& Simmie, 2008; Frey \& Osborn, 2013). In the same vein is the essay by Caliandro and Sacco (Caliandro \& Sacco, 2011), which states that the creative and cultural capacity of a country is a precondition for development and innovation in all other fields of knowledge and technology.

A very interesting aspect in the investigation on measuring the impact of culture on economic development is the employment potential of the cultural sector. The focus in this case is not strictly linked to the economic value of a cultural asset, but considers what is the economic value in terms of human capital produced by culture. We are witnessing more what Ellmeier defined in 2003 as the "marketization of culture and the culturalization of the market" (Ellmeier, 2003), which refers to the ever-closer relationship between two worlds, for a long time seen as separate and unconnected, where culture has become a more commercial issue and the economy is increasingly influenced by culture. In a knowledge-based society, new forms of work are being developed, which for the moment have not yet fully been defined and recognized, and a new social class that has been defined the "creative class" (Florida, 2002; Florida, 2005). The "creative class" would thus become the new factor of economic development allowing us to grow an environment characterized by tolerance, technology and skills, and these three factors would represent the decisive factor for economic growth. According to a study conducted in the United States on the sample of 219 regions (Florida, 2002), there would be a positive correlation between the presence of technology, tolerance and talents, defined as the $3 \mathrm{Ts}$, and the rate of employment and income.

Furthermore, the use of labour-intensive methods helps small and medium-sized enterprises, and decreases costs ranging from $10 \%$ to 30\% (Lawrence \& Werna, 2009; Nypan, 2015)

Paradoxically, although these factors can be crucial for the development of a community, the relative goods are often also threatened by natural causes (earthquakes, floods, landslides), economic (pollution, building and infrastructure abuse,

\footnotetext{
${ }^{1}$ According to the European Construction Industry Federation, in 2017, the restoration and maintenance of cultural assets was equal to $25,1 \%$ of the value of European construction industry. In France, for example, the cultural assets generated $€ 9.1$ billion in 2016.
} 
technological impact), socio-cultural (population density, mass tourism, urban decorum and incivility) and institutional (poor levels of prevention and protection of cultural heritage) (World Bank [WB], 2001; Gard'ner, 2007; Licciardi \& Amirtahmasebi, 2012; United Nations Office for Disaster Risk Reduction, 2012; Jygyasu, 2016; Stanton-Geddes \& Soz, 2017).

\section{Methodology}

That said, what is important to verify in this paper is how the widespread presence of historical private real estate can contribute to the development of a given territory. The case-study will be Italy, where the concentration of historical private real estate is particularly high. In fact, there are 54 UNESCO sites in Italy, which is the highest number in the world. According to the 2017 data published by the UNWTO, Italy appears to be the third European destination (fifth in the world) by the number of international tourists, equal to 58.3 million overnight, and 44 billion dollars of money collected (United Nations World Tourism Organization [UNWTO], 2018). With specific reference to cultural tourism, last year the sector represented $56 \%$ of overnight stays at national level and $67 \%$ of foreign leisure tourism spending, with an average spending of between 30 and $40 €$ a day more (129€ against $90 €$ ) compared to a seaside holiday maker. Moreover, in 2017 the so-called "cultural landscape tourism" or "experience-based tourism" increased in Italy. This type of tourism connotes the "memory" of an event, which is itself part of the added value of the final tourism product, responding to the need of the tourist to access the intangible aspects of the tourist experience and to immerse him or herself in the history and culture of the place visited (Cohen, 1979; Pine \& Gilmore, 1998; Corrigan, 1999). This form of tourism takes place in mostly non-urban areas, including landscapes, traditional products, craftsmanship, as well as museums and monuments, representing $7 \%$ of total annual stays in Italy and $8 \%$ of tourist holiday expenditure (Manente, 2018).

The mapping of the immense historical and artistic heritage of a country is complex and uncertain, both in terms of the nature of the object being examined, and its destination, and obviously its ownership. As far as our case study is concerned, however, it is possible to reduce the risk of arriving at unreliable results if we concentrate and restrict the property subject to restrictions pursuant to art.10 and 13 of the Code of Cultural Heritage and Landscape, introduced in Italy with the legislative decree 22nd January 2004, n. 42, pursuant to art. 10 of the Law of 6 July 2002, n. 137. The immovable property (as well as the mobile ones) of private property are subjected to protective measures of the aforementioned Code ("constrain"), if they are the object of a declaration (art. 13) that satisfies "the artistic, historical, archeological, and ethno-anthropological interests". If, on the one hand, this constraint, imposed by the State, attributes to the buildings, a public relevance and social utility, on the other hand, in fact, it limits their possibilities of use and imposes a significant burden on their owners in terms of costs of conservation and maintenance.

The Italian Code, in fact, recognizes the private owner, holder or possessor of a property belonging to the cultural heritage of the country, a conservation obligation (art. 1, paragraph 5) and of compliance with the protection legislation for usage and enhancement activities of the same asset (art. 1, paragraph 6).

Focusing on the Italian reality, a first mapping is now easy using the portal "Vincoli in Rete" ("Restrictions on the web portal"), recently created and edited by the Istituto Superiore per la Conservazione e il Restauro, which contains a platform of data and information on cultural heritage at national, regional and local levels. This database currently contains approximately 210.000 tied assets between Real Estate and Property Assets of Non-Private Property, which, for the sake of clarity, contain all the remaining legal conditions (real estate belonging to the State, the regions, other local public entities, non-territorial public entities, ecclesiastical institutions and religious institutes, private non-profit legal entities). Restricted properties are classified according to the type of property, of which $92,2 \%$ is represented by architectural assets; 5\% from archaeological heritage and the rest from parks and gardens.

If we want to limit ourselves here to map real estate asset to private individuals, the first step has been to filter the data contained in the platform, according to the title of property (private) and type of real estate.

As of June 2018, there were 33.301 buildings, castles, villas and other architectural assets, representing more than $16,7 \%$ of the total historical-artistic capital (Monti \& Cerroni, 2018).

The tied patrimony constituted by archaeological assets, inclusive of all the facilities, sites and monuments considered and recognized as of cultural, historical and artistic interest represents $5 \%$ of the tied real estate in the country, of which almost $10 \%$ is privately owned. Lastly, more than 250 parks, gardens, woods and boulevards are registered at national level. Also, in this case, there is a significant burden on the part of individuals, considering that they hold or own almost $15 \%$ of this asset.

To this end and to verify any correlations at the local level between the density of tied private assets and the development of urban centers, all the provincial capitals and metropolitan cities of the Italian regions have been selected for this purpose. For reasons of fairness, the municipalities of Trento, Bolzano and Aosta have been excluded, because, in the light of the data of the "Restrictions on the web" portal, they do not have any tied private property. According to ANCITEL 
Data (Associazione Nazionale Comuni Italiani [ANCITEL], 2017), the urban centers were, therefore, divided into "large cities" (cities with over 250.000 inhabitants), "medium-sized cities (between 60.000 and 250.000 inhabitants) and "small cities" (with less than 60.000 inhabitants).

Instead, the correlation between the concentration of private real estate assets under constraints and the impact of cultural activities in the economy has been analyzed at provincial level, intersecting data provided by the portal "Vincoli in Rete" ("Restrictions on the web portal"), with those related to the added-value of historical-artistic assets at current prices (Fondazione Symbola \& UnionCamere, 2018).

To estimate the investments necessary for maintenance and, above all, the enhancement of the aforementioned assets, the starting point of our investigation was the estimates of Fondazione Bruno Visentini (Monti, 2015) carried out since 2015, on the assumption that the private historical dwellings in Italy where about 30.345, of which 15.525 were palaces, 7.820 villas, plus 7.000 among castles, fortresses and towers, by administering a questionnaire to a sample of members belonging to the Italian Association of Historic Houses (ADSI), the main representative organization of the owners of historic houses in the country. Specifically, the forms were forwarded to over 3.000 members during the months of November 2015 and 2017. The responses received represent $0,7 \%$ of the target universe mentioned above and its territorial distribution allows, with some reservations, the definition of the statistical sample (Monti \& Cerroni, 2018). This estimate is substantially confirmed by the aforementioned most recent questioning of the database of the Istituto Superiore per la Conservazione e il Restauro and, therefore, valid as reference sample.

The objective was to estimate the actual maintenance costs and investments incurred for owners of the dwellings.

\section{Results}

The most interesting results that emerge from the mapping concern the diffusion of the heritage on a local scale. The results highlighted in Figure 1 are particularly significant; the histogram, in fact, shows the historical-artistic real estate asset for each region, breaking down this value between private property and the remaining non-private assets. Emilia-Romagna stands out for the largest total number of historic buildings (27.029 units), the region of Marche for the largest number of historic properties linked to private individuals (9.691 units) and Molise for the highest percentage concentration of the latter $(68,6 \%$ of the total), while Sicily stand out for the miniscule weight of private historical assets on the aggregate number (at just $1 \%$ ).

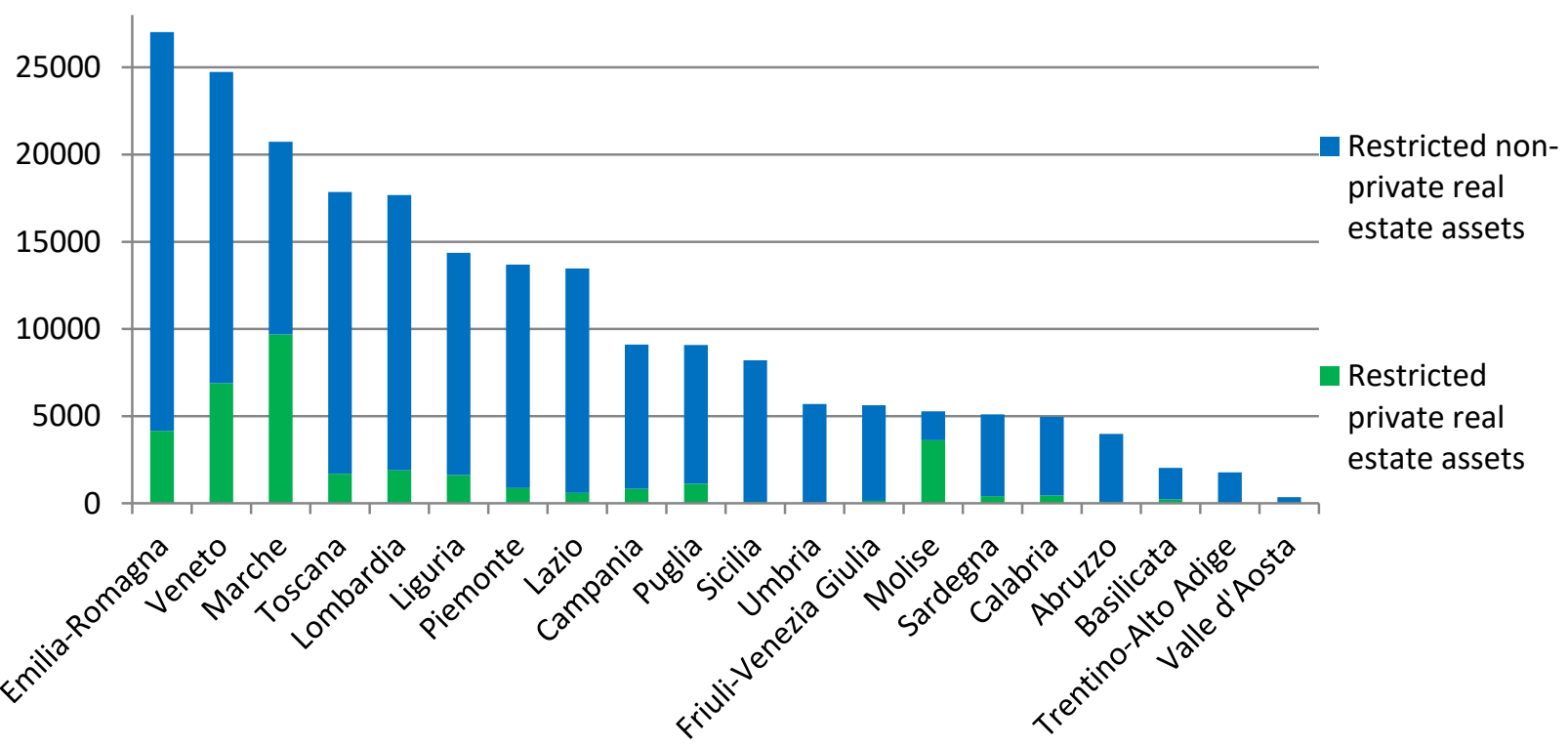

Figure 1. Number of private historical-artistic real estate asset for each region

Source: Our figures derive from "Istituto Superiore per la Conservazione e il Restauro" (Higher Institute for Conservation and Restoration, refresh 9th June 2018)

Regarding the density of private real estate assets in Italy, a tied real-estate property is registered every 1759 residents (see Figure 2). Leading the list is Molise, Marche, Veneto and Liguria, with less than 1.000 inhabitants per private historical residence, and at the tail end is Sicily, Umbria and Abruzzo, with over 15.000 inhabitants for private real estate. 


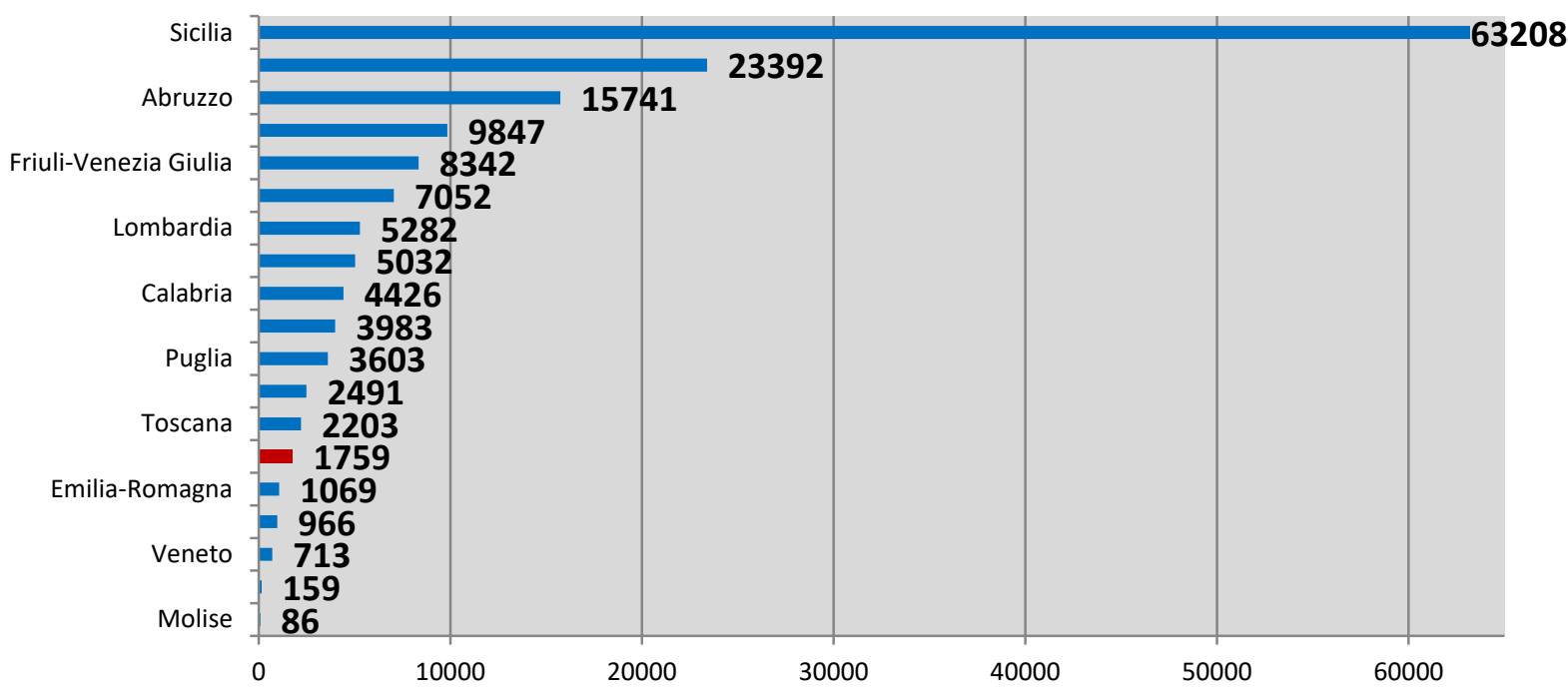

Figure 2. Density of restricted private real estate assets for number of residents at regional level (absolute values at regional level)

Source: Istituto Superiore per la Conservazione e il Restauro" (Higher Institute for Conservation and Restoration, refresh 9th June 2018)

Instead, the data highlighted by the figure 3 attempts to provide a first answer to the complex question of the weight of restricted private real-estate property assets in medium and small urban areas, increasingly at risk not only of depopulation and an ageing population, but also of marginalization and loss of their local dimension (Monti \& Cerroni, 2017).

Indeed, the results show a greater presence of private real estate in small Italia cities (with a population of less than 60.000), compared to urban centers of medium (60.000 - 250.000 inhabitants) and large cities (over 250.000 inhabitants). Taken as a median reference the municipality of Frosinone (a private property bound for every 5758 inhabitants), 19 of the Italian municipalities of the provincial capital of less than 60.000 inhabitants out of a total of 32, equal to 59,38\%, have greater concentration of private real estate assets under restriction (black in Figure 4), compared with $45 \%$ of medium-sized ones (green in Figure 3) and 50\% of large metropolitan cities (see purple color in Figure 3).

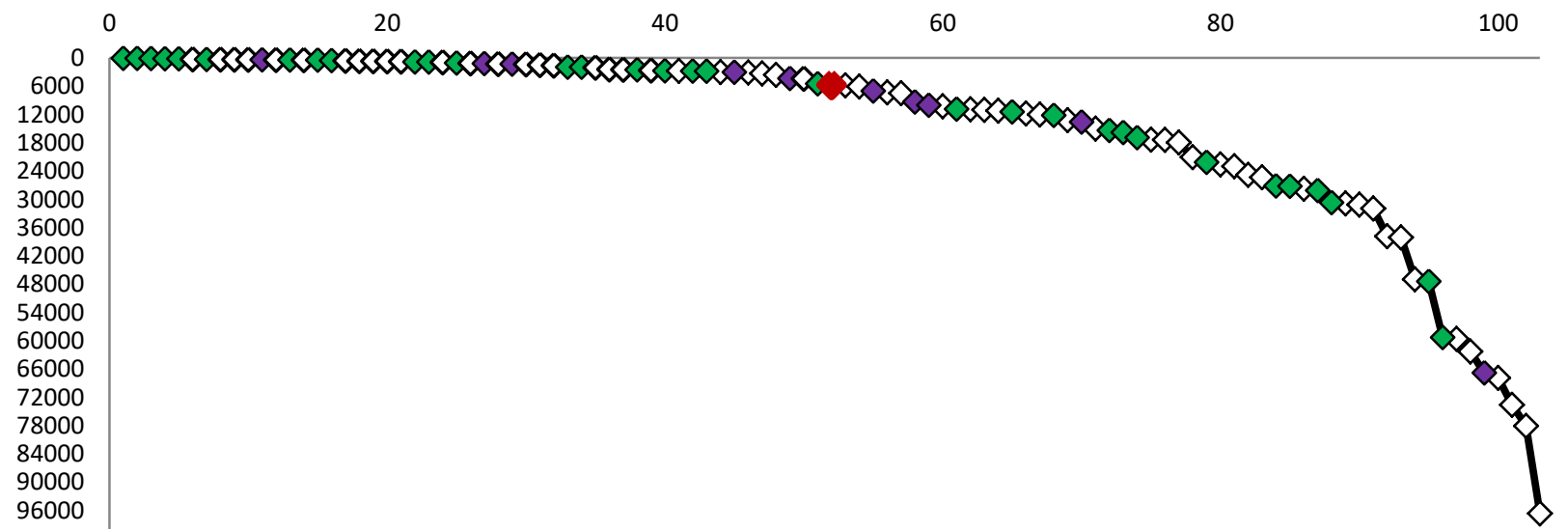

\begin{tabular}{|c|l|}
\hline LARGE CITIES & \\
\hline MEDIUM-SIZED CITIES & \\
\hline SMALL CITIES & \\
\hline MEDIAN (FROSINONE) & \\
\hline
\end{tabular}

Figure. 3. Concentration of restricted private real estate assets for number of residents at municipal level (absolute values at municipal level)

Source: Istituto Superiore per la Conservazione e il Restauro" (Higher Institute for Conservation and Restoration, refresh 9th June 2018) 
If we consider the first ten provincial capitals/metropolitan cities by density of restricted private real estate, we note that the first five positions are occupied by urban centers with a population of less than 60.000 (Siena, Ascoli Piceno, Urbino, Fermo, Isernia). In these local realities, the relationship "of proximity" between population and cultural-historical private assets certainly lays the foundations for the consolidation of a link between the cultural heritage represented by immovable property and the local community of reference. In line with what is recognized by the Council of Europe Framework Convention on the value of cultural heritage for the development of a society (Council of Europe [CoE], 2005), therefore, these private tied assets are an asset of the past with which local populations identify themselves, regardless of who owns their property, as a reflection of their tradition in a state of continual evolution.

It is evident, therefore, how the enhancement of private real estate assets, particularly relevant in smaller centers, can represent a stimulating challenge for the economic, social and cultural growth of those territories.

For this reason, the results of Figure 4 provide a first, significant projection of the weight of restricted private real-estate assets in Italy, linking data on impact of cultural activities in the economies at provincial level, provided by UnionCamere and Fondazione Symbola in their last report (Fondazione Symbola \& UnionCamere, 2018), with the relative concentration of private real-estate assets under restriction2.

With reference to the 52 provinces with higher density of tied private property with respect to the median value (see red color in Figure 4), it reveals that 78,84\% has an impact of cultural activities by value-added, on the total local economy below the national average, equal to $0,2 \%$ (blue color in Figure 4). Suffice it to say that among the top ten local economies with a higher intensity of cultural activities (Agrigento, Palermo, Siracusa, Enna, Firenze, Roma, Messina, Viterbo, Carbonia-Iglesias, Sassari), only Viterbo has a significant concentration of tied private real estate assets for number of residents.

Therefore, these results seem to suggest, on the one hand, the still significant weight of non-private assets in the cultural and creative industry and, on the other hand, a lack of integrated interventions to further enhance the private cultural assets under restriction.
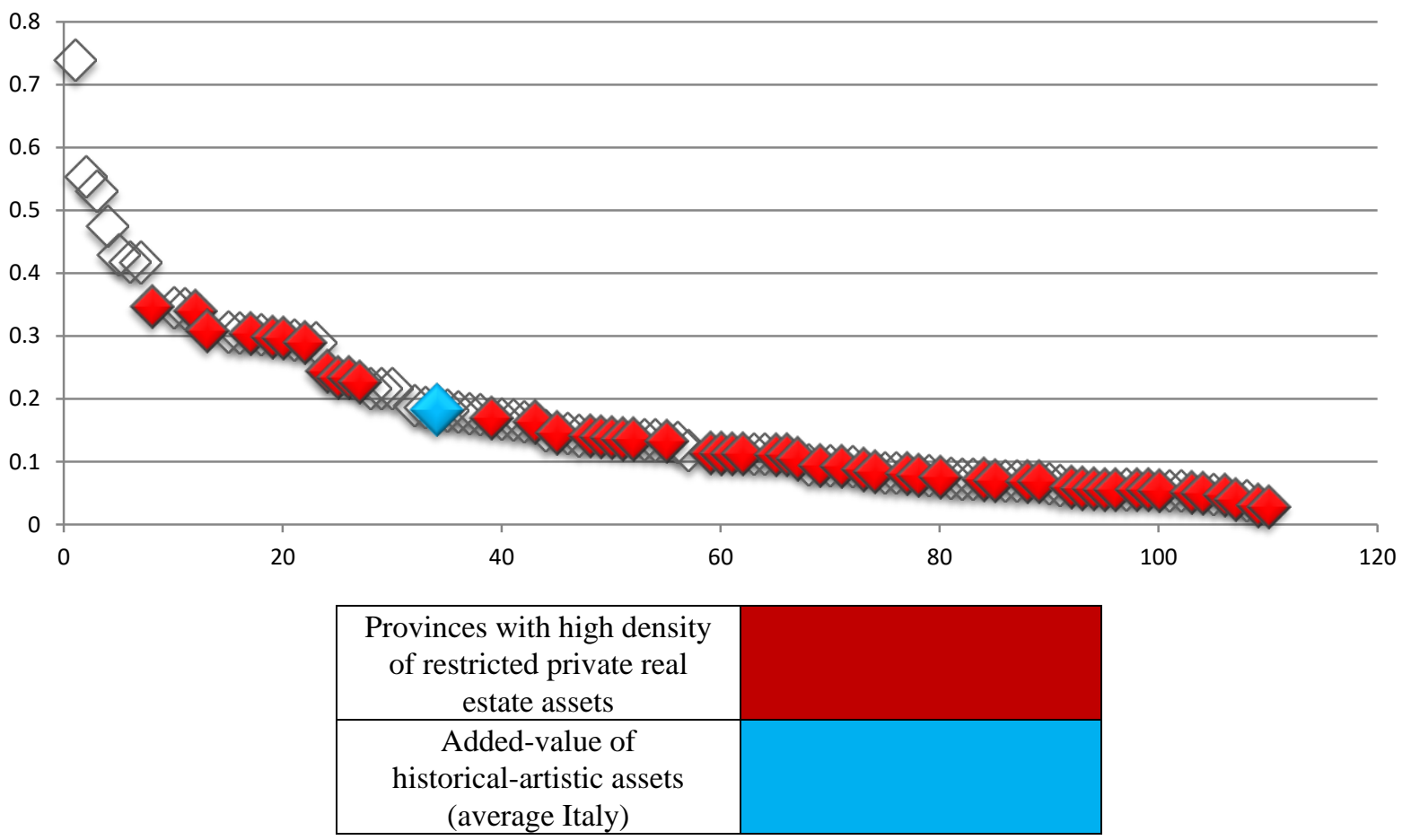

Figure 4. Density of restricted private real estate assets and effect of cultural activities in the local economy (percentage values at provincial level)

Source: Fondazione Symbola - UnionCamere

\footnotetext{
${ }^{2}$ Please note that the intensity of cultural activities in the local economy is calculated as the percentage of added-value at current prices of cultural enterprises which operate in the sector of conservation, management and enhancement of historical-artistic assets at local level.
} 
The main reason of this latest observation should be found into the reducing capacity of private owner to invest in their historical assets. Starting from the results of the analysis of Fondazione Bruno Visentini, it emerges that over the last 10 years (2007-2017), private individuals have invested over 30 billion euros in the sector, of which 21 billion euros derived from exceptional expenditure and the remaining 9 billion euros from routine maintenance. This means that each historical dwelling has requested an average of almost 90.000 euros per year between conservation and restoration costs of a routine and exceptional nature.

It is also interesting to compare the unit costs calculated in the latter survey and the average annual unitary expenses calculated in 2015 (Monti, 2015), which cover the period 2005-2014.

Figure 5 shows the investments for the protection and maintenance of private properties with the two measurements compared. For the buildings, the average annual cost per housing unit has increased by $2 \%$ compared to the 2015 survey. In contrast, castles and villas recorded an opposite trend, with a significant contraction of average annual unitary expenses, for both the routine and exceptional expenditure.
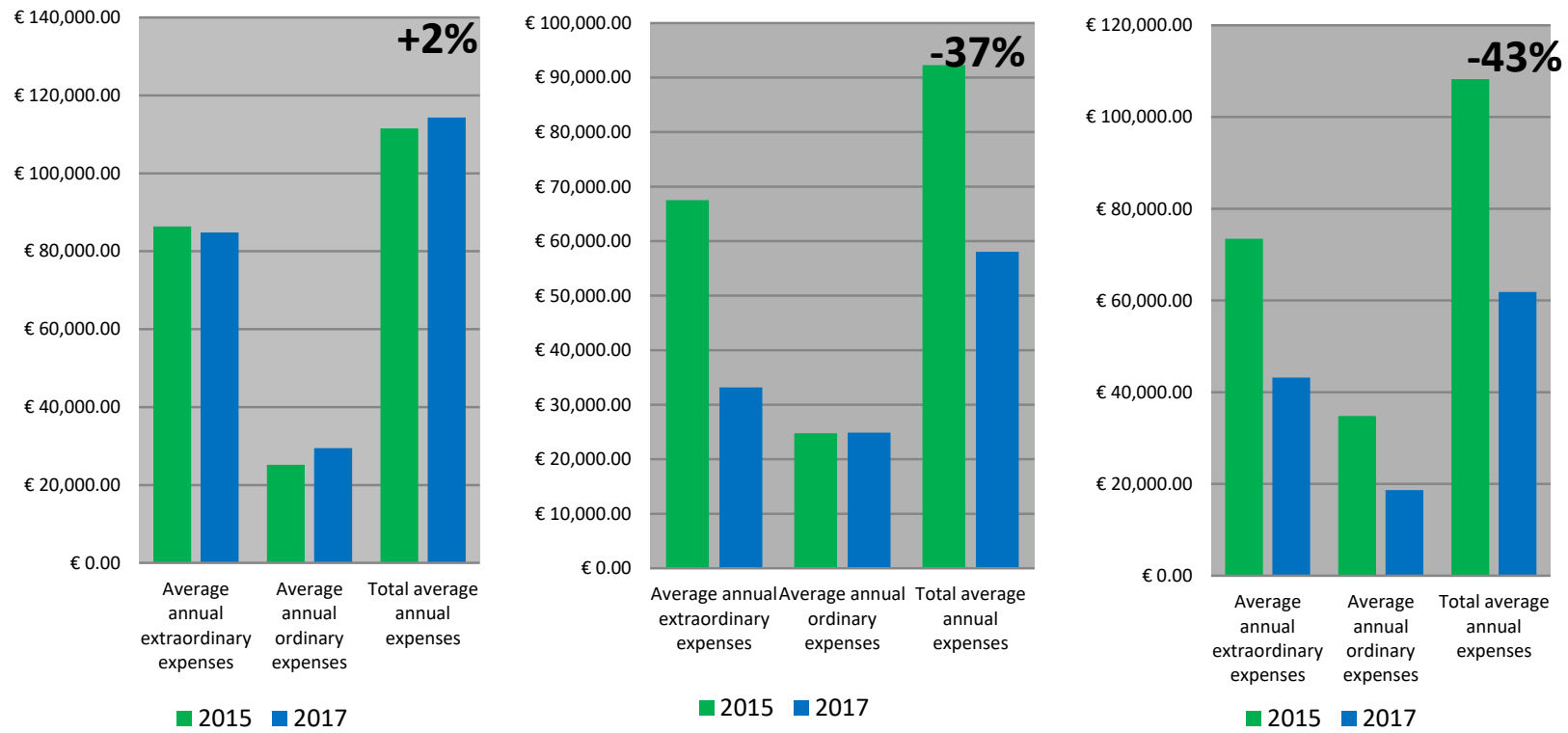

Figure 5. Average annual unitary expenses 2015-2017. (Building on the left, Castles in the center, Villas on the right)

Source: Fondazione Bruno Visentini (ADSI Data)

The data is even more negative when the respondents' spending forecasts for the next 2018-2022 period are considered, in which a percentage decrease of $37 \%$ is estimated. This is the result of a widespread and growing lack of confidence, on the part of owners, in the legislatures ability to provide facilitating measures to help this sector.

However, studying the possibility of incentives or investments to support the enhancement of this patrimony that we can demonstrate a certain relationship between heritage and the development of the territory concerned.

\section{Conclusion}

In conclusion, this cross analysis of the necessary investments for the enhancement of private cultural property, the concentration of tied private real-estate assets in economically marginalized areas, and the relevance of cultural activities in the local economy shows how the development potential linked to this heritage has been largely unfulfilled. Therefore, it is necessary to promote a change of perspective among institutions and stakeholders at all levels (national, regional and local), in order to shift the focus from the "guardian of private property" (private owner) to the cultural real estate assets, including its economic (as a multiplier) and socio-cultural potential (expression of values, believes, knowledge and traditions of a local community). In fact, it is easy to reveal a positive correlation between cultural assets, creativity and entrepreneurship, where historical-artistic assets, also of a private property kind, can function as the "Genius loci" for new ideas and entrepreneurship initiatives, especially for young people (Monti \& Cerroni, 2016). Moreover, the sector of historical-artistic assets shows several potentials in Italy, particularly in rural areas and small cities, but at the same time it denounces the lack of support for private owners, as well as a significant disconnection between the potential of attraction of these tied assets and the relative impact of cultural activities at local level. Therefore, these findings call for comprehensive interventions in the sector, in order to boost the socio-economic potential of historical real estate property, where the history of families as guardian of private assets is still inextricably tied to that of the local community. 
In addition, at supranational level, a European intervention would be desirable, not only to promote creative enterprises, but also to pay due attention to cultural industries that deal with the management and enhancement of historical-artistic cultural assets, as well as to harmonize national regulations in this sector, which has long been recommended by the European Commission (European Commission [EC], 2010). Therefore, a specific cultural heritage model boosting the economic growth of smaller cities should be investigated.

\section{Acknowledgements}

The proof reading is provided by Jan Erik Kermer.

\section{References}

ABS Australian Bureau of Statistics. (2001). Measuring wellbeing: Frameworks for Australian Social Statistics. In Australian Bureau of Statistics. Canberra.

Autor, D., Levy, F., \& Murnane, R. J. (2003). The Skills Content of Recent Technological Change: An Empirical Exploration. In Quarterly Journal of Economics, 118(4), 1279-1334. https://doi.org/10.1162/003355303322552801

Bakhshi, H., Mc Vittie, E., \& Simmie, J. (2008). Creating Innovation. Do the creative industries support innovation in the wider economy?. In Research Report NESTA. London

Bardi, A., \& Goodwin, R. (2011). The Dual Route to Value Change: Individual Processes and Cultural Moderators. In Journal of Cross-Cultural Psychology, 42(2), 271-287. https://doi.org/10.1177/0022022110396916

Baumol, W., \& Bowen, W. (1965). On the performing arts: An anatomy of their economic problems. In American Economic Review, 55.

Bille, T., \& Schulze, G. (2006). Culture in urban and regional development. In Ginsburg, V., \& Throsby, D. (eds.) (2006). Handbook of the Economics of Art and Culture, 1, 1052-1099, Elsevier, Amsterdam.

Bodo, C., \& Bodo, S. (2008). La coesione sociale e le politiche pubbliche per la cultura. In Economia della Cultura. Rivista trimestrale dell'Associazione per l'Economia della Cultura, n.4/2007

Caliandro, C., \& Sacco, P. L. (2011). Italia Reloaded. In Il Mulino. Bologna.

Campa, G., \& Bises, B. (1982). La spesa dello Stato per i beni culturali. Cedam, Padova.

Causi, M., \& Leon, P. (1990). La politica dei beni culturali. In Notediricerca CLES.

Cohen, E. (1979). A Phenomenology of Tourist Experience. In Sociology, 13(2), 179-201. https://doi.org/10.1177/003803857901300203

Corrigan, P. (1999). La sociologia dei consumi. In Franco Angeli Edizioni, Milano.

Council of Europe (2005). Council of Europe Framework Convention on the Value of Cultural Heritage for Society. Council of Europe Treaty Series - No 199, Faro.

Council of Europe. (1998). On the cultural routes of the Council of Europe. In Resolution, 4(98).

Cox, G. (2005). Cox Review of Creativity. In Business: Building on the UK's Strengths. HM Treasury, London.

Crompton, J. L. (2006). Economic Impact Studies: Instruments for Political Shenanigans?. In Journal of Travel Research, 45(1), 67-82. https://doi.org/10.1177/0047287506288870

Crompton, J. L., \& McKay, S. L. (1994). Measuring the Economic Impact of Festivals and Events: Some Myths, Misapplications and Ethical Dilemmas. In Festival Management and Event Tourism, 2(1), 33-43. https://doi.org/10.3727/106527094792335782

Ellmeier, A. (2003). Cultural Entrepreneurialism: On the Changing Relationship Between the Arts, Culture, and Employment. In The International Journal of Cultural Policy, 9(1). https://doi.org/10.1080/1028663032000069158a

European Commission (2010). Unlocking the potential of cultural and creative industries. COM (2010) 183 final. Brussels: European Commission

European Commission. (2007). How culture and the arts can promote intercultural dialogue in the context of the migratory and refugee crisis. In Luxembourg: Publications Office of the European Union. ISBN 978-92-79-67387-0

European Construction Industry Federation. (2018). Key Figures 2018 - activity 2017. Retrieved from http://www.fiec.eu/en/library-619/key-figures.aspx

European Parliament. (2007). European Parliament Resolution of 10 April 2008 on cultural industries in Europe. 
(2007/2153(INI)).

European Parliament. (2009). Hearing on the economic role of heritage in a time of financial crisis.

Everitt, S. (2009). Arts and Economic Prosperity III: A review. In Cultural Trends, 18(4), 315-321. https://doi.org/10.1080/09548960903268139

Farina, S. (2003). L'impatto economico e occupazionale della cultura: modelli teorici e best practice. In Federculture, Il settore cultura nei grandi comuni italiani. parte IV: 70-79

Florida, R. (2002). The Rise of the Creative Class: And How it's transforming work, leisure, community and everyday life. In Perseus Book Group. New York.

Florida, R. (2005). The Flight of the Creative Class: The New Global Competition for Talent. In WGBH Educational Foundation.

Fondazione Symbola, \& UnionCamere. (2018). Io sono Cultura - Rapporto 2018. In Quaderni di Symbola.

Frey, C. B., \& Osborne, M. A. (2013). The future of employment: how susceptible are jobs to computerization? In Oxford Martin School Working Paper. Oxford OX1 1PT, United Kingdom Department of Engineering Science.

Gard'ner, J. (2007). The Economics of Heritage: Integrating Costs and Benefits of Heritage into Government Decision Making. In Department of the Environment and Water Resources Workshop. Government of Australia.

Heilbrun, J., \& Gray, C. (2004). The Economics of Art and Culture. In Cambridge University Press. Cambridge.

Heng, T. M., Choo, A., \& Ho, T. (2003). Economic Contributions of Singapore's Creative Industries. In Economic Survey of Singapore First Quarter 2003. Singapore Ministry of Trade and Industry.

Herrera, C. (2002). Cultural Capital and Its Impact on Development. In Encuentro. IDB Cultural Centre, 43, 1-13.

Hofstede, G. (eds.) (2001). Culture's consequences. In Thousand Oaks. CA: Sage.

Ingelhart, R. (2000). Culture Matters: How Values Shape Human Progress. In Basic Books. New York.

International Labour Organisation. (2018). Back to the Future. Challenges and opportunities for the future of work addressed in ILO sectoral meetings since 2010. In Sectoral Policies Department. Working Paper No. 317.

Jagodzińska, K., Purchla, J., Senetra, S. J., Niedźwiecki, P., Tylus, K., Vandesande, A., ... \& Verpoest, L. (2015). Cultural Heritage Counts for Europe. In Cultural Heritage Counts for Europe project.

Jensen, J. (2002). Identifying the links: Social Cohesion and Culture. In Canadian Journal of Communications, 27(2), 141-151. https://doi.org/10.22230/cjc.2002v27n2a1289

Jigyasu, R. (2016). Reducing Disaster Risks to Urban Cultural Heritage: Global Challenges and Opportunities. In Journal of Heritage Management. n.1. https://doi.org/10.1177/2455929616649476

Kancel, S., Itty, J., Weill, M., \& Durieux, B. (2013). L'apport de la culture à l'èconomie en France. In Inspection générale des finances e Inspection générale des affaires culturelles.

KEA European Affairs. (2017). Mapping the Creative Value Chains. A study on the economy of culture in the digital age. Final report. In Luxembourg: Publications Office of the European Union. ISBN 978-92-79-66638-4.

Kenan Institute Asia (KIAsia). (2009). The Economic Contribution of Thailand's Creative Industries. In KIAsia \& Fiscal Policy Institute.

Lawrence, R., \& Werna, E. (eds.) (2009). Labour Conditions for Construction: Building cities, decent work \& the role of local authorities. In Oxford: Wiley-Blackwell.

Licciardi, G., \& Amirtahmasebi, R. (2012). The Economics of Uniqueness: Investing in Historic City Cores and Cultural Heritage Assets for Sustainable Development. In International Bank for Reconstruction. The World Bank, Washington. https://doi.org/10.1596/978-0-8213-9650-6

Manente, M. (2018). Scenario ed Economia Turistica. Focus Regionale 2017. In XVIII Conferenza "Italia e il Turismo Internazionale. Risultati e tendenze per incoming e outgoing nel 2017. CISET.

Matarasso, F. (1997). Use or ornament? The social impact of participation in the arts. In Comedia.

McCallum, D. (2007). Regeneration and the historic environment. In Forsyth, M. (2007). Understanding Historic Building Conservation, Wiley Blackwell. https://doi.org/10.1002/9780470691823.ch4

McLendon, T., Klein, J., Listokin, D., \& Lahr, M. L. (2010). Economic Impacts of Historic Preservation in Florida. In Florida Department of State. 
Monti, L. (2015). Il potenziale del patrimonio immobiliare storico-privato. Stima extra-gettito IVA nel periodo 2016-2020 con l'introduzione di incentive e relativo metodo di calcolo. Fondazione Bruno Visentini. Retrieved from http://www.fondazionebrunovisentini.eu/

Monti, L., \& Cerroni, R. (2016). La valorizzazione del patrimonio culturale dell'ADSI attraverso percorsi di alternanza scuola-lavoro. In Amministrazione in Cammino LUISS, ISSN: 2038-3711.

Monti, L., \& Cerroni, R. (2017). Le città del futuro: la "terza via" possibile tra smart cities e smart villages. In Amministrazione in Cammino LUISS, ISSN: 2038-3711.

Monti, L., \& Cerroni, R. (2018). Il potenziale socioeconomico del patrimonio immobiliare storico privato in Italia. In $14^{\circ}$ Rapporto Annuale FederCulture 2018. Impresa Cultura Comunità Territori Sviluppo. Gangemi Editore International.

Myerscough, J. (1988). The Economic Importance of Arts in Britain. In Policy Studies Institute. London, p.88, ff.

Nypan, T. (2015). A proposal for a design to develop European statistics on the socio-economic contributions of the physical cultural heritage. In Koen Van Balen, K., \& Vandesande, A. (eds.) (2015). Heritage Counts. Reflections on Cultural Heritage Theories and Practices. A series by the Raymond Lemaire International Centre for Conservation, KU Leuven, vol. 2, Garant: Antwerp - Apeldoorn, 2015, ISBN 978-90-441-3330-1.

Peacock, A. (1969). Welfare economics and public subsidies to the arts. In Manchester School of Economic and Social Studies, 4. 323-35 [reprinted in Towse] (1997), 2.

Picard, T. (2018). Le poids économique direct de la culture. In Culture chiffres 2018/1 ( $\left.n^{\circ} 1\right)$. 18 pages. https://doi.org/10.3917/culc.181.0001

Pine, B. J., \& Gilmore, J. H. (1998). Welcome to the experience economy. In Harvard Business Review, 76(4).

Portier, J. M. (2002). La disciplina dei beni culturali nell'ordinamento giuridico francese. In Diritto e gestione dell'ambiente.

Potts, J., \& Cunningham, S. (2008). Four models of the creative industries. In International Journal of Cultural Policy, 14(3), 217-232. https://doi.org/10.1080/10286630802281780

Reeves, M. (2002). Measuring the Economic and Social Impact of the Arts: A Review. In Arts Council. London.

Robinson, K. (2001). Mind the Gap: The Creative Conundrum. In Critical Quarterly, 43. https://doi.org/10.1111/1467-8705.00335

Santagata, W., \& Signorello, G. (2000). Contingent Valuation of a Cultural Public Good and Policy Design: The Case of "Napoli Musei Aperti". In Journal of Cultural Economics, 24, 181-204. https://doi.org/10.1023/A:1007642231963

Santagata, W., Segre, G., \& Trimarchi, M. (2007). Economia della cultura: la prospettiva italiana. In Economia della Cultura. a. XVII.

Stanton-Geddes, Z., \& Soz, S. A. (2017). Promoting disaster resilient cultural heritage. Washington, D.C.: World Bank Group.

Throsby, D. (2001). Economics and Culture. In Cambridge University Press. Cambridge.

Throsby, D. (2011). Cultural capital. In Towse, R. (eds.) (2011). Handbook of Cultural Economics. Edward Elgar, Cheltenham, pp. 142-146. https://doi.org/10.4337/9780857930576.00026

Titan, E., Voineagu, V., \& Todose, M. (2008). The Impact of Cultural-Creative Industries on the Economic Growth. A Quantitative Approach. In Annals of Faculty of Economics. University of Oradea, Faculty of Economics, 2(1), 930-935.

United Nations Educational Scientific and Cultural Organisation. (2005). Convention on the Protection and Promotion of the Diversity of Cultural Expression. Unesco, Paris.

United Nations General Assembly. (2010). Resolution on Culture and Development. A/C.2/65/L.50, New York.

United Nations Office for Disaster Risk Reduction. (2012). How to make cities more resilient: A handbook for local government leaders - a contribution to the global campaign 2010-2015 making cities resilient - my city is getting ready!. Geneva. Retrieved from http://www.unisdr.org/files/26462_handbookfinalonlineversion.pdf

United Nations Office for Disaster Risk Reduction. (2017). Europe Leads on Resilient Cultural Heritage. Retrieved from https://www.unisdr.org/archive/52042

United Nations World Tourism Organisation. (2018). UNWTO Tourism Highlights 2018 Edition. ISBN: 978-92-844-1986-9. 
Vallerand, C. (2013). How does culture drive and enable social cohesion and inclusion?. In UNESCO Workshop on Culture and Sustainable Development. Culture: A driver and an enabler of social cohesion, Culture's contribution to addressing urban violence. Hangzhou, China.

Wells, J. (2009). Dar es Salaam. In Lawrence, R. \& Werna, E. (eds.) (2009). Labour Conditions for Construction: Building cities, decent work and the role of local authorities. Wiley-Blackwell, p.187. https://doi.org/10.1002/9781444306446.ch5

World Bank. (2001). Cultural heritage and development: a framework for action in the Middle East and North Africa. In Doc. 22559. Washington.

\section{Copyrights}

Copyright for this article is retained by the author(s), with first publication rights granted to the journal.

This is an open-access article distributed under the terms and conditions of the Creative Commons Attribution license (http://creativecommons.org/licenses/by/4.0/). 